\title{
The role of interaction in online learning environments: students' experiences and perspectives
}

\section{Rafael Leonardo da Silva}

Mestrando em Estudos da Linguagem no

Programa de Pós-Graduação em Estudos da

Linguagem (PPGEL) da Universidade Estadual de

Londrina; Londrina; Paraná; Brasil.

rafaelleon2107@gmail.com

Abstract: This paper is situated in the research area of distance learning in virtual environments.

This article analyses the views of Brazilian students on the interaction in an online course taught and tutored by pre-service teachers of Letras - Inglês from UEL in 2013. The data point to three perspectives: (i) interaction as a clarification tool for the content from the lessons and/or the required tasks in the course, (ii) interaction as a valuable tool for the social construction of knowledge, and (iii) interaction as a compulsory task. The analysis may contribute to further research in the online course research field.

Key-words: online learning; online forums; students' views

\section{Telma Nunes Gimenez}

Professora Doutora da UEL - Universidade Estadual de Londrina; Programa de Pós-

Graduação em Estudos da Linguagem (PPGEL);

Pos-doutorado na University of London; Londrina;

Paraná;. Brasil.

e-mail: tgimenez@uel.br

Resumo: Este trabalho está inserido na área de pesquisa de ensino à distância em ambientes virtuais. Neste artigo, analiso perspectivas de alunos brasileiros sobre a interação em um curso online ministrado por alunos-professores de Letras - Inglês da UEL em 2013. Os dados apontam para três perspectivas: (i) a interação como uma ferramenta para clarificação do conteúdo exposto nas lições e/ou nas atividades requeridas no curso, (ii) a interação como uma valiosa ferramenta para a construção social do conhecimento, e, por fim, (iii) a interação como uma tarefa obrigatória. Esta análise pode contribuir para pesquisas posteriores na área de cursos online.

Palavras-chave: ensino online; fóruns virtuais; perspectivas de alunos 



\section{Introduction}

Nowadays, the use of digital technologies in language education has become increasingly important due to the development of new tools, especially with the expansion of the internet (PAIVA, 2012). Along with that, there has also been an increase in the number of blended courses (which include face-to-face and online tasks) or those offered fully online.

Online learning has been extensively studied in recent years (NUGENT, 2009; MASON, 2011; LAMBROPOULOS, 2012; HAMILTON; HARLAND, 2012; SUNG; MAYER, 2012). One of the areas that has received a lot of attention is the role of interaction in online courses. Interactivity is a key element in this kind of learning environment due to the importance of building relationships between students and teachers, as well as among learners (LIU, 2008; NUGENT, 2009; HAMILTON; HARLAND, 2012). Such relationships seem to be necessary in order to build a "sense of community", considering the lack of interaction to be one of the reasons why learners drop out of such courses (DUEBER; MISANCHUK, 2001).

This paper presents students' views on the role of interaction in online learning, after an experience of a web-based course in Brazil. The data collected reveals advantages and disadvantages of collaborative learning in online environments. In order to support our arguments and compare our findings to different contexts, this paper also presents a review of the previous literature in the area.

\section{Literature Review}

This section brings the theoretical background that underlies this research paper. First, there is an overview of distance education courses as well as a description of the 
different types of online courses. Then, we present some studies that analyze the relevance of interaction in these web-based learning environments, which is intrinsically related to the purpose of this research. Lastly, we bring information about what an online forum is, since it was the primary instrument for the subjects of this study to communicate during their online course.

\subsection{Online Learning}

Online learning, or E-learning, has been the subject of constant debate and research (NUGENT, 2009; MASON, 2011; LAMBROPOULOS, 2012; HAMILTON; HARLAND, 2012; SUNG; MAYER, 2012). The growing importance of distance education in online environments is directly related to the development of new technological learning resources. Paiva (2012), for instance, presents an overview of the use of technology in the English language classroom, relating it to the growth of the internet in the last decade. A result of this development, according to the author, is a change in how people see and experience the world. Paiva emphasizes the vast amount of tools available today to enhance online language learning, for example, the Wikipedia to find new information, social media to interact with others and Prezi to create presentations.

Web-based courses are part of this broad context of learning technology, and recent studies have analyzed the characteristics of such courses. Perry and Pilati (2011), for instance, discuss the differences in types of online learning environments, which can be fully online or hybrid (part face-to-face, part online). Whether the course will take place only on the Internet or both in face-to-face and online contexts depends on the course developer. The authors also point to the important role of the teacher, who needs to be mindful of the specificities 
of an online course. Among these specificities, it is worth mentioning the vast variety of possible interactive tools and the flexibility in terms of time, which enables the student to perform the tasks according to his/her own agenda. The lack of instructors' awareness of the specific characteristics of E-learning may lead to an unsuccessful experience (PERRI; PILATI, 2011).

In Brazil, there still seems to be some resistance against online education. A local study carried out by Corrêa and Santos (2009) presents face-to-face undergraduate students' beliefs about online courses in academic settings. There were comments emphasizing the inefficacy of distance education which results in unprepared professionals. In fact, Vieira (2007) remarks that advertisements for online courses contribute to the reinforcement of negative opinions, since they may portray such courses as facilitated means to obtain a university degree. These views, however, are not shared by distance learners, who stress the need for discipline and autonomy in order to achieve success in online courses (VIEIRA, 2007).

Despite this opposition, many state and federal universities offer certain subjects within undergraduate courses to be taken in a distance education environment. A federal law, Decreto federal $n^{\circ}$ 5.622/05 (BRASIL, 2005), allows universities to offer up to $20 \%$ of their courses using an online platform (PIRES, 2012). In addition, blended or fully online undergraduate courses are becoming increasingly common; a census by INEP (BRASIL, 2011) estimates that around 15\% of higher education students are enrolled in such courses. In other countries, the use of distance learning is more established; several American and British universities, for example, offer online courses for free, available for anyone to take. Some of these courses are available at Coursera, an online platform. ${ }^{1}$
${ }^{1}$ Available at: <www. coursera.org $>$. Accessed on: 18 jun. 2013. 


\subsection{Interaction in Online Courses}

Social presence is an important factor for the success of an online course (SUNG; MAYER, 2012); that is, when the instructor is available to answer questions and interact with learners, he/she increases students' motivation and involvement. Intimacy and immediacy (p. 1739) are required in this social presence; in other words, the instructor has to engage personally in the course, enabling students to identify him/her as a "real human being" rather than a robot, and also answer eventual questions as soon as possible, showing engagement in the course.

Nugent (2009) emphasizes the role of teacherstudent interaction to increase learners' motivation. According to this author, there is a correlation between the relationship of teachers and students and how well students do in a course. Good relationships are tied to better grades, and bad relationships to worse grades. If there is no interaction, then, the student may not perform so well, be it a face-to-face class or an online course. There is also a need, however, for students and teachers to have "measurable and attainable goals to create experiences with and exposure to success" (NUGENT, 2009, p. 82).

It is not only teacher-student interaction that matters in online environments. Other types of interaction exist in an online context, such as student-student and student-content. The communication between the participants, as well as with the tutors of a course, is important for building a learning community where learners do not feel isolated but part of a whole (DUEBER; MISANCHUK, 2001). This sense of community is also important for student motivation; lack of interaction in a web-based course is, according to the authors, one of the reasons why students drop out. Dueber and Misanchuk (2001) also relate the sense of belonging to safety; learners may feel more secure sharing information with people 
whom they are comfortable with. In a course such as the one analyzed in this paper, it is the tutor's responsibility to find ways in which the members can familiarize with each other.

Liu (2008) also emphasizes the relevance of learning communities for student development. Through active communication and discussions, learners build their knowledge along with other peers instead of only receiving information from the teacher. The author values interaction for cognitive reasons, since "[d]iscussions in this learning process will facilitate individual cognitive growth so that learners will come to their own conclusions based on collaboration through interpersonal communication" (p. 4). In order words, students will learn better if they have access to other points of view from colleagues, which helps them to build their own theories.

Moreover, it is essential to distinguish the two forms of interaction that can happen in an online course: synchronous and asynchronous. The first requires the participants of the interaction to be available online at the same time so that communication can occur, while the latter does not present such time limitation and therefore participants can interact whenever their availability allows. Examples of synchronous tools are chat rooms, web conferences and instant messaging, while e-mails, online forums and blogs can be considered asynchronous (HUANG, 2012). In the course taken by the participants of this research, the main means of communication chosen was the online forum, an asynchronous tool.

\subsubsection{Online Forums}

An online forum is a discussion area where "members can post discussions and read and respond to posts by other forum members" (CYPRUS, 2013). In 
forums, there can be various simultaneous discussions, distinguished by different "threads". Participants' posts in a thread are usually organized in chronological order.

According to Mason (2011), online forums are effective learning tools. Therefore, it is imperative that the instructor engages in the discussion, in order to encourage learners to participate (BALAJI; CHAKRABARTI, 2010). About the instructor role in the forum, Lambropoulos et al. (2012) point that

[i]nstructors should declare early in the course their expectations of students on how to participate and acquire the best out of the discussion forum. This declaration may consist of directions regarding how many and how often students should post on the discussion board, what should be the pattern of their contribution, how the students should approach the subject, and in general what is expected of them. [...] (p. 23)

Furthermore, Lambropoulos et al. (2012) divide user participation in online forums in two categories: active and passive. An active user reads and posts in the discussions, not only receiving knowledge but also transmitting it. On the other hand, the passive user only reads posts, therefore not expressing his/her opinion. The authors divide these categories in different levels, namely low, medium and high. In this inquiry, students were required to be active users, since in the online course responding to forums were mandatory activities.

Mason (2011) also presents a survey with students' comments about the effectiveness of an online forum that they experienced in an academic setting; most respondents were in favor of tasks involving discussions, since it is possible to have contact with other ideas and perspectives. Another comment was that online tasks help to put theory into practice. Even so, there were negative remarks as well, such as the need for the project to be 
compulsory so that learners do it and the preference for non-online tasks. Such results were presented through a table, showing students' own perspectives. Specifying the reasons behind these arguments was not required.

\section{Methodology}

This research was carried out at a public university in the northern Paraná state, Brazil. The subjects chosen for this study were Brazilian pre-service and in-service teachers who participated in an online course called "A Short History of the English Language", taught and tutored by preservice English language teachers of the State University of Londrina which took place from July $1^{\text {st }}$ to September $16^{\text {th }}$, 2013. This was the first time when such pre-service teachers designed an online course. Data was collected through a questionnaire, which the students responded at the end of the course; the subjects are identified with the letter $\mathrm{S}$ followed by a number, e.g. S1, S2, S3, etc..

The data was analyzed qualitatively; subjects' answers were compared, so that differences and similarities between their experiences could be observed. The previous research prsented in the literature review functions as background reading to the data with a view to comparing this study's results to other online learning contexts.

\subsection{The course}

The course "A Short History of the English Language" aimed at presenting to the students an overview of the evolution of the history, literature and spelling in the English language. The virtual platform chosen for this course was Moodle, an open-source website frequently used in Brazilian universities. Moodle allows users to use a range of resources in their courses, such as videos, images, and online forums. The course was divided into five modules, namely: (i) Old 
${ }^{2}$ (Original in

Portuguese) Durante

o curso, apresentamos

atividades que

requeriam ou não a

interação entre alunos

e entre alunos e

tutores. Entendemos, aqui, interação como a troca de informações entre diferentes pares, de forma que o conhecimento não seja adquirido apenas através do conteúdo disposto nas lições, mas também do compartilhamento mútuo de opiniões e crenças. Em sua opinião, tais interações influenciaram no seu processo de aprendizado? Por quê?

a) Se sim, como a interação o influenciou?

b) Se não, como você acredita que $o$ aspecto da interação poderia ter sido melhorado no curso? Na sua opinião, estas mudanças contribuiriam para o seu processo de aprendizado?
English; (ii) Middle English; (iii) Early Modern English; (iv) Modern English; (v) World English. The course was taught entirely in English and students were expected to use only this language.

Each module was, then, subdivided in three lessons. Every lesson presented a specific task to be carried out. Quizzes, wikis and replying to forums were some of the tasks assigned. As my focus is on the interaction that took place in the forums, I will develop this aspect further in the data analysis by presenting an overview of the forums included in the course.

\subsection{The instrument of data collection}

As mentioned before, the data analyzed in this research were collected through a questionnaire, which should be answered in Portuguese (as opposed to the course, which was taught in English), which was required for course completion. The questionnaire was composed of nine questions, designed with the purpose of collecting students' impressions, criticism and suggestions for the course. For this research more specifically, all the findings were taken from the answers to one specific question, namely (translated from the Portuguese):

During the course, we presented activities that either required or not interaction among students and tutors. Interaction is here understood as exchange of information among different peers, so that knowledge is not only acquired through the content presented in the lessons, but also in the mutual sharing of opinions and beliefs. In your opinion, did such interactions influence your learning process? Why?

a) If yes, how did interaction influence you?

b) If not, how do you believe the interaction factor could be improved in this course? In your opinion, would these changes contribute to your learning process? $?^{2}$ 


\subsection{Data analysis procedures}

This qualitative study follows an interpretive paradigm in which the task-related forums were analyzed according to the degree and type of interaction they required. The categories corresponding to the respondent's answers emerged from the data.

A comparison of the answers was done and similarities and contrasts identified.

\section{Analysis}

\subsection{Interaction in the course}

In this first part of the analysis, we will present a description of the interaction that took place in each of the five modules of the course "A Short History of the English Language". This description may help explain some of the responses to the questionnaire, which will be presented later.

The first module, Old English, required the students to post their preferred topic of the module and how that knowledge could be used in an EFL classroom. The main interactants would be the students enrolled in the course and T1. We could observe that, even though interaction between students was not explicitly asked for in this task, some students agreed with each other, presenting preferences in common.

\section{Student A:}

$\mathrm{Hi}$

In my opinion the three topics were interesting, but one thing took me more attention it was when we learned about the evolution of the language and the changes that happened in views of forming the English as we know today. ${ }^{3}$

\section{Student B:}

I agree with you, [Student A], it's very important to konw the evolution of the language. Hugs,
${ }^{3}$ Since such forum posts were part of the course, students were required to reply using the English language.

Table 1. Example of interaction in Module 1, Task 3 
Middle English, the second module, presented three forums as tasks, in which students shared their preferred contents of the lesson and, following the model of a forum presented in the first module, their applicability in the EFL classroom. Once again, in the interchange of information between students no conflicts could be found; sometimes, a student agreed with a peer and only added a complementary comment. There was also a strong presence of the tutor in this module, giving feedback to students (see table 3).

\section{Student A:}

The information presented in this lesson was very useful to me because I didn't know how French influenced the English language. The facts about the kings' life were very interesting. I enjoyed a lot watching the videos and read the texts of the sites. The most interesting part was the one that mentions how kingdoms were conquered, like the crown had to be conquered and not inherited.

I think it's possible to use the same videos and texts from this section to show to the students the origin of the English language and all the history that involve this influence.

\section{Student B:}

Yes [Student A]. It was very interesting. I always thought that to be a king was just be a royal family. But the story showed us that the King fought hard to get the throne.

Table 2. Example of interaction in Module 2, Task I

Student:

Hello.

The information in section 1 are important to understand the complex way that a country is formed, in this context to learn about the Norman Invasions represents more knowledge and a useful way to understand the movies that we can watch nowadays. [...] The same way I guess that TV series are a good manner of teaching English in schools with TV or other medias, because it deals with the students' reality when they have been showing in our houses as much as it could be in classrooms [...]. 
T2:

Hi [Student].

That's right. Those TV series are an amazing tool to teach history, and they can understand better the idea of learning English or any other language when we demonstrate how they can use it in their daily life.

Thanks for sharing.

See you!

Table 3. Example of interaction in Module 2, Task I (2)

The third module, Early Modern English, presented only one task which consisted of a forum, where students should answer a question on English pronunciation. Interaction was almost non-existent in this lesson, probably due to the objective aim of the required task (see table 4).

Modern English, the next module, presented a forum designed to serve as a platform for students to post their answers to questions for two lessons, lessons one and three. Interaction among students was not found in this forum, but there are many examples of tutors' feedback on the responses, praising or suggesting the further development of the students' response.

Student A:
Hi, my lesson is about Newfoundland dialect present in Canadian
areas and the New Zealand dialect.
Hugs.
T4:
Hi [Student A]!
Good work! You did not have to do all the file to complete this
exercise, but it's very good. I just think the example would be better
if it was from a real-life situation, for example a song or a tv show. It's
fine the way you did, it would be a better contact with the culture
and the accent.
Very Good!

Table 4. Example of interaction in Module 4, Tasks I and III. 
Finally, in the last module, World English, there were technical problems in the forums, and discussion for all the tasks presented in this module were organized in only one topic. Similarly to the two previous modules, almost no exchange of information among students could be observed.

Summing up, clear evidence of interaction was found mostly in the first two modules. However, there were no differences in opinion, as students agreed with each other and added comments whenever possible. In the analysis, we expect to find, on the students' perspective, explanations for this kind of interaction and the lack of it in the last three modules.

${ }^{4}$ Since the questionnaire was originally presented to the participants in Portuguese and they were expected to answer it in the same language, their responses were translated in this paper and the original excerpts were added as footnotes.

\subsection{Students' perspectives on the course interactions}

As mentioned previously, students' perspectives related to the interaction that took place in the course were collected through the following question ${ }^{4}$ :

During the course, we presented activities that either required or not interaction among students and tutors. Interaction is here understood as exchange of information among different peers, so that knowledge is not only acquired through the content presented in the lessons, but also in the mutual sharing of opinions and beliefs. In your opinion, did such interactions influence your learning process? Why?

a) If yes, how did interaction influence you?

b) If not, how do you believe the interaction factor could be improved in this course? In your opinion, would these changes contribute to your learning process?

A careful reading of the questionnaire responses yielded three major categories referring to value (or not) of the interactions: (i) Interaction as a tool for clarification; S1, S2, S7, S8; (ii) Interaction as valuable 
tool for the social construction of knowledge; S3, S5, S6, S7, S9, S10, S11; and (iii) Interaction as a compulsory task. S3, S4, S10

Each of these categories will be described in detail next. Note that, since the selections were originally written in Portuguese, the translation to English is provided in the main body of the text and the originals are given as footnotes.

\subsubsection{Interaction as a tool for clarification}

Four, among the 11 subjects of this research, mentioned that, by mutual collaboration with peers, they were able to understand better what was asked in each task. The results of the tasks were, then, directly influenced by comments from others. The four responses that fit this category are presented below.

"The interaction between colleagues helps to understand each question better, since one complements the other's idea." (S1)

"Yes. Some information that many times I left unnoticed, when a colleague commented on the forum, I reflected about it and commented to myself: look, I did not remember of this detail, or look, I had not noticed this information, and so on. " $(\mathrm{S} 2)^{6}$

"It facilitated to have a better understanding of the topic to be discussed." (S7) ${ }^{7}$

"Yes, I believe that it helped regarding content understanding, but there were so many participants that it was impractical to keep up with everyone." (S8) ${ }^{8}$

First of all, it is necessary to establish what is to understand. According to the Cambridge Dictionary Online, to understand is "to know the meaning of something, or to know how a person feels and why the person behaves in a particular way". In this context, we may assume that understanding, from the other
5 “A interação entre colegas que ajuda a entender melhor cada questão, pois um complementa a ideia do outro." (S1)

6 "Sim. Algumas informações que muitas vezes eu deixava passar desapercebidas, quando um colega comentava no fórum eu refletia sobre e comentava comigo mesma: olha, eu não lembrava deste detalhe, ou olha, eu não tinha percebido esta informação, e assim por diante." (S2)

7 "Facilitou para ter um melhor entendimento do tópico a ser discutido." (S7)

8 "Sim, creio que ajudou na compreensão dos conteúdos, porém havia tantos participantes que era inviável ficar a par da participação de todos." (S8)

${ }^{9}$ Available at: $<$ http:// dictionary.cambridge.org/ us/dictionary/americanenglish/understand_1>. Accessed on: 8 oct. 2013. 
${ }^{10}$ Available at: < http:// learnweb.harvard.edu/ alps/tfu/infolb.cfm>. Accessed on: 8 oct. 2013. hints presented in these excerpts, relates to a textual interpretation on a superficial level. This is evidenced especially by S2 ("[...] I had not noticed this information [...]). A text from the Harvard website, entitled What is understanding? ${ }^{\text {10 }}$, defines this concept in a more practical way: "So what is understanding? In a phrase, understanding is the ability to think and act flexibly with what one knows. To put it another way, an understanding of a topic is a "flexible performance capability" with emphasis on the flexible." Bringing this definition in the context analyzed here, understanding leads to student capability of doing the tasks required.

Another aspect that is worth mentioning in these responses is the concept of complementation, as introduced by S1 ([...] one complements the others' idea.). Complementation leads to an idea of completion; it seems as though there were parts of the content missing, and the comments from the peers helped to solve the puzzle, one that has only one interpretation. This is mind, it is possible to identify a lack of a critical perspective during the course. Students did not challenge each other's opinions and the validity of the content presented in the lesson, and this aspect may have been overlooked by the tutors while monitoring the discussions, since they are responsible guiding students during the online course (SUNG; MAYER, 2012).

Although S8 agrees with his/her peers that cooperation led to a better understanding, s/he also problematizes the course structure ("[...] it was impractical to keep up with everyone.”), pointing one of the factors that might lead to a not so fruitful use of the forums. This subject's perspective shows unfamiliarity with online courses, which usually present many more students than a physical classroom (specially MOOCs, such as the Coursera, already introduced in this paper). This unfamiliarity with the features of online courses and forums will be discussed further in this paper. 


\subsubsection{Interaction as valuable tool for the social construction of knowledge}

Seven students stated, in their questionnaires, that the interactions contributed to their learning process, since they were able to have contact with different perspectives on the same subjects. Some excerpts from these students are presented below.

"I believe that the exchange of information is fundamental, but I think I did not interact as I could." (S5) ${ }^{11}$

"Yes, we can observe and compare how we understand each activity." (S6) ${ }^{12}$

"In the perceptions of seeing new ways of learning." (S7) ${ }^{13}$

"Yes, this interaction influenced because I learned even more with the different answers from the participants." (S9) ${ }^{14}$

"Yes, because that way [we are] able to exchange experiences, interpret in different ways, exchange and receive information... It is still a new form [of interaction] but it certainly helps us a lot in distance education courses." (S11)

First, S5 points to what is an agreement between all the five subjects presented below, that is, the importance of collaboration in online courses. However, this student also adds self-criticism ([...] I did not interact as I could. $[\ldots])$. It is possible to infer, from this excerpt, that the student relates the lack of the interaction to lack of student engagement. S6 agrees with S5, presenting a new perspective on what understanding, a concept introduced previously, can be.

According to S6, understanding seems to be a personal construction. In other words, instead of merely comprehending at a textual level what was transmitted
11 "Acredito que a troca de conhecimento é fundamental, mas acho que não interagi como poderia." (S5)

12 "Sim, podemos observar e comparar como compreendemos cada atividade." (S6)

13 "Na percepções de ver novas formas de aprendizado." (S7)

14 "Sim, esta interação influenciou porque aprendi ainda mais com as diferentes respostas dos participantes." (S9)

15 "Sim porque desta forma capazes de trocar experiências, fazer interpretações de diversos modos, podemos trocar $\mathrm{e}$ receber informações, é uma forma ainda nova para muitos, mas com certeza nos ajuda muito nos cursos de EAD." (S11) 
16 "Certamente

influenciou, no entanto acredito que se as discussões através de fóruns fosse mais livre seria mais produtivo. Pois a partir do momento em que esta é uma atividade obrigatória e com assunto já pré-determinado, os estudantes tendem a fazê-la de uma forma mais mecânica portanto menos espontânea e estimulante. Sem a 'obrigação' penso que as discussões seriam melhores, inclusive com conteúdos melhores." (S3) through a question and/or a text, for this subject, there may be different forms of understanding the same piece of information. S6 also mentions the negotiation of interpretations as essential to the social learning process in an online course. This response resonates in S7's discourse, in which the subject points to "new ways of learning", and in S9's answer ("[...] I learned even more with the different answers from the participants.")

Additionally, S11 agrees with his/her colleagues, although he/she defines forums as a "new form of interaction"; we can assume that this platform was unknown to this subject prior the course, and, in consequence, some adaptation was necessary. This inexperience with the platform chosen for the course may be one of the contributing factors, along with what was already presented, for the way interaction happened throughout the modules. Since students did not know how to use a forum properly, there should have been instruction related to the forum tools prior the course, as pointed by Lambropoulos et al. (2012).

\subsubsection{Interaction as a compulsory task}

Lastly, we present one negative perspective regarding interaction in the online course, which is related to the unnatural aspect of the discussions carried out on it. The excerpts from the three subjects who agree on this matter are the following:

"It certainly influenced, however, I believe that if the discussions through the forums were freer it would have been more productive; as since that it is a mandatory activity with a preestablished subject, the students tend to do it in a mechanical, less spontaneous and stimulant way. If no 'obligation' existed, I think the discussions would be better, including better content." $(\mathrm{S} 3)^{16}$ 
"Actually, I think this aspect was somewhat vague, I do not know if I did all the interactions that I should have done or if I missed something $[\ldots]]^{\prime \prime}(\mathrm{S} 4)^{17}$

"I believe that interaction contributes a lot indeed, but I did not notice that happening, not in this course. I noticed that people posted what was being asked for but did not interact among themselves. Maybe that happened due to the difficulty of posting within the deadline." (S10)"18

S3 approaches the discussions in this course as artificial, pointing that non-guided discussions would be more productive. In other words, if the forums had not $\mathrm{n}$ bee created specifically for tasks, the learning outcome might have been better. This issue will be developed further.

S4 and 10 agree on the vagueness of how the interaction was dealt with in this course. According to S4, the importance of interaction may not have been emphasized by the tutors when designing the course; collaboration was a task that he/she should do, that is, a mandatory activity, showing a practical example of what was presented by S3. S10, in turn, says that responses in the forum were related to the questions being asked in the tasks, and little exchange of information could be observed in the modules, showing a student's interpretation which is similar to what was presented in the brief analysis of the forums.

\subsection{Discussion of results}

Through the analysis, two different views on the concept of understanding could be found. The first is related to the comprehension of the course content on a textual level, while the second is linked to a social construction of knowledge, after having contact with different perspectives from peers. It is possible, then, to
17 "Na verdade, eu acho que ficou meio vago esse quesito, eu não sei se fiz todas as interações que deveria ter feito ou se faltou alguma coisa [...]" (S4)

18 "Eu acredito que a interação colabora bastante sim, mas não percebi isso acontecendo, não neste curso. Notei que as pessoas postavam o que estava sendo pedido mas não interagiam entre si. Talvez isso tenha acontecido pela dificuldade de postar no prazo." (S10) 
conclude that interaction was perceived as a contributing factor to the learning progress of those individuals. As Liu (2008) mentions, the development of a "learning community" among the course participants helps in the construction of knowledge, and, in this point, the course can be considered successful according to the subjects' point of view. Evidence of knowledge construction through the contact with peers' perspectives can be found in the examples presented in my analysis of the forums, where one student agrees with the other and adds a comment.

On the positive side, it was also possible to identify the frequent presence of the instructor to give feedback to students in the forums, especially in Modules 2 (Middle English) and 4 (Modern English). As I have already presented in the literature review (NUGENT, 2009; SUNG; MAYER, 2012; PERRI; PILATI, 2011), teachers' (and tutors') engagement in discussions is crucial for student motivation and development; they are responsible for guiding learners through the forums. This aspect, however, seems to have been overlooked by the research subjects in this study, who seem to have considered as interaction only the moments where they exchanged messages and responded to other students.

There are students who reacted negatively to the use of forums as well. Two subjects, S4 and S10, deemed interaction in the course as "vague". Instructors may not have given instructions to what students were supposed to do in the forums, which was vital, since evidence of their inexperience with online forums can be found in the data. Perry and Pilati (2011) point to the importance of teachers' being aware of the specificities of an online course, and giving clear directions on how to use the tools presented in the platform is one of them. The students' answers indicate that the tutors were not aware of the need for teaching how to use a forum properly before 
assigning tasks, and, therefore, interaction in this course was not as advantageous as it could have been.

Moreover, another negative point mentioned by the subjects was the fact that all the forums were part of mandatory tasks. Such students would rather have had freer discussions, where they could have discussed a range of different topics related to the course. This perspective conflicts with Mason's (2011) study, which presents students' comments about the use of online forums in e-learning; Mason's subjects state that online tasks have to be compulsory, otherwise they are not done. Putting these contrasting views into perspective, it is possible to conclude that there should be a balance between mandatory and non-mandatory tasks as far as online forums are concerned. In this course, however, there was a forum available for students to start their own discussions and post their own ideas. This fact was probably overlooked by the tutors, who could have motivated learners to share their own points of view on that section, thus developing a shared sense of safety and identification between learners (DUEBER; MISANCHUK, 2011).

\section{Conclusion}

In this paper, we aimed at analyzing students' perspectives on the interaction through online forums in a course about the history of the English language. There were varied responses, which were categorized in three major themes: (i) interaction as a clarification tool for the content presented in the lessons and/or the required tasks in the course, (ii) interaction as a valuable tool for the social construction of knowledge, and, finally, (iii) interaction as a compulsory task.

Most of the students agree that interaction was certainly helpful through the development of the course. 
Some aspects, however, could be improved: (i) tutors could have presented directions to students on how to use a forum properly and create their own discussions, since problems related to forum usage were observed; (ii) tutors could have been clearer on what they expected of students when assigning tasks, showing lack of awareness of some of the specificities of online courses, and (iii) being aware of how to use forums adequately, students could have developed their own discussions, posting comments not only for mandatory tasks, but also for creating an interest on other topics related to the broader area of the history of the English language.

Finally, this study has some limitations. As this course took place in a Brazilian setting, the results and analysis presented here may not apply to different contexts, with different themes and more experienced tutors. However, this paper does present contributions to further research in the online course research field, and also help in the development of courses in virtual environments. 


\section{References}

BALAJI, M. S.; CHAKRABARTI, D. Student Interactions in Online Discussion Forum: Empirical Research from 'Media Richness Theory' Perspective. Journal of Interactive Online Learning, v. 9-1, 2010.

BRASIL. Decreto № 5.622 de 19 de dezembro de 2005. Regulamenta o art. 80 da Lei ${ }^{\circ}$ 9.394, de 20 de dezembro de 1996, que estabelece as diretrizes e bases da educação nacional. Disponível em: < http://www.planalto.gov.br/ ccivil_03/_ato2004-2006/2005/Decreto/D5622.htm>. Acesso em: 12 jul. 2014.

BRASIL. Censo da Educação Superior, INEP/MEC, 2011.

CORRÊA, S. C.; SANTOS, L. M. M.. Preconceito e educação a distância: atitudes de estudantes universitários sobre os cursos de graduação na modalidade a distância. Educação Temática Digital, v. 11-1, 2009, p. 273-297.

CYPRUS, S. What is an Internet Forum? Available at: <www. wisegeek.org/what-is-an-internet-forum.htm $>$. Accessed on: 3 Jun. 2013.

DUEBER, B.; MISANCHUK, M. Sense of Community in a Distance Education Course. Available at: <http://billdueber. com/dueber-misanchuk.pdf $>$. Acessed on: 23 apr. 2013.

HAMILTON, M.; HARLAND, J. Evaluating the quality of interaction in asynchronous discussion forums in fully online courses. Journal of Distance Education, v. 33, 2012, p. 5-30.

HARVARD LEARNWEB. What is understanding? Available at: < http://learnweb.harvard.edu/alps/tfu/infolb.cfm $>$. Accessed on: 8 oct. 2013.

HUANG, X. Synchronous and asynchronous communication in an online environment: faculty experiences and perceptions. The Quarterly Review of Distance Education, v. 13-1, 2012, p. 15-30. 
LAMBROPOULOS, N.; FAULKNER, X.; CULWIN, F.

Supporting social awareness in collaborative e-learning. British Journal of Educational Technology, v. 43-2, 2012.

LIU, S. Student Interaction Experiences in Distance Learning Courses: A Phenomenological Study. Online Journal of Distance Learning Administration. v. 11-1, 2008.

MASON, R. B. Student Engagement with, and Participation in, an E-forum. Educational Technology \& Society, v. 14-2, 2011.

NUGENT, T. T. The impact of teacher-student interaction on student motivation and achievement. Available at: < http:// udini.proquest.com/view/the-impact-of-teacher-studentpqid:1992441271/>. Accessed on: 23 apr. 2013.

PAIVA, V. L. M. O. English Language teaching and learning in the Age of Technology. Available at: <www.veramenezes. com/abrapui2012.pdf>. Accessed on: 22 apr. 2013.

PERRY, E. H.; PILATI, M. L. Online Learning. New Directions for Teaching and Learning, v. 128, 2011.

PIRES, C. O. S. O EAD no Brasil evolui e melhora a aceitação do mercado. Available at: <http://webinsider.uol.com. br/2012/11/29/o-ead-no-brasil-evolui-e-melhora-a-aceitacaodo-mercado/>. Accessed on: 28 May 2013.

REIS, S. Reflexões sobre uma jornada com destino à pesquisa. Rev. Brasileira de Linguística Aplicada, v.6, n. 1, 2006, p. 101117.

SCHWANDT, T. Três posturas epistemológicas para a investigação qualitativa: interpretativismo, hermenêutica e construcionismo social, in DENZIN, N. K. , LINCOLN, Y. S. e colaboradores. O planejamento da pesquisa qualitativa: teorias e abordagens, Porto Alegre: Bookman e Artmed, 2006.

SUNG, E; MAYER, R. E. Five facets of social presence in online education. Computers in Human Behavior, v. 28, 2012. 
UNDERSTAND. In: Cambridge Dictionary Online. Available at: <http://dictionary.cambridge.org/us/dictionary/americanenglish/understand_1>. Accessed on: 8 oct. 2013.

VIEIRA, M. C. EAD: O mito da educação fácil. 2007. 78p.

(monograph for completion of licensure in Pedagogy) Pontifícia Universidade Católica do Rio Grande do Sul, Porto Alegre. 


\section{Attachment \#1}

\section{A Short History of the English Language \\ Questionário de finalização de curso}

As perguntas a seguir nos ajudarão a compreender a percepção dos nossos alunos sobre o curso que foi recentemente finalizado. Além disso, há um espaço para sugestões e críticas para que possamos melhorar o curso, caso este seja oferecido novamente no futuro. Garantimos o anonimato dos alunos, de modo a não relacionar as opiniões aqui contidas a suas identidades pessoais.

1) Qual a sua idade?
a) $18-21$
b) 21-25
c) $25-30$
d) 30 ou mais

2) Onde você reside?
a) Londrina
b) Outra cidade no norte do Paraná
c) Outra cidade no Paraná
d) Outro

3) Em sua opinião, qual foi o aspecto mais interessante do curso? Por quê?

4) Você teve de enfrentar algum problema relacionado ao aspecto linguístico durante o curso? Explique.

5) Você teve de enfrentar algum problema relacionado à utilização do Moodle durante o curso? Explique. 
6) Você teve de enfrentar algum problema, além dos dispostos nas questões anteriores, durante o curso? Explique.

7) Que tipos de atividade você achou mais úteis, ou mais gostou, durante o curso? Por quê?

8) Durante o curso, apresentamos atividades que requeriam ou não a interação entre alunos e entre alunos e tutores. Entendemos, aqui, interação como a troca de informações entre diferentes pares, de forma que o conhecimento não seja adquirido apenas através do conteúdo disposto nas lições, mas também do compartilhamento mútuo de opiniões e crenças. Em sua opinião, tais interações influenciaram no seu processo de aprendizado? Por quê? 
a) Se sim, como a interação o influenciou?

b) Se não, como você acredita que o aspecto da interação poderia ter sido melhorado no curso? $\mathrm{Na}$ sua opinião, estas mudanças contribuiriam para o seu processo de aprendizado?

9) Você tem alguma crítica ou sugestão a respeito do curso em geral?

Recebido em 03/02/2014

Aceito para publicação em 24/07/2014 